\title{
PeRformanCe OF OVERWINTER COVER CROPS IN COASTAL LEBANON
}

\author{
S. Rouphael ${ }^{1}$, F. El Mekdad ${ }^{1}$, A. Mouawad ${ }^{1}$, M. Mjallal' ${ }^{1}$, \\ E. Touma ${ }^{1}$, S. El Hajj ${ }^{1}$, A. K. Hajj ${ }^{2}$, T. Atallah*1 \\ ${ }^{1}$ Department of Plant Production, Faculty of Agricultural Sciences, Lebanese \\ University. \\ ${ }^{2}$ Lebanese Agricultural Research Institute, Lebaa station, South Lebanon. \\ *corresponding author: Therese Atallah \\ therese.atallah@gmail.com
}

(Received July 2018- Accepted September 2019)

\begin{abstract}
S. Rouphael, F. El Mekdad, A. Mouawad, M. Mjallal, E. Touma, S. El Hajj, A. K. Hajj, T. Atallah. 2019. Performance of overwinter cover crops in coastal Lebanon. 20(1): 89-103.

The effect of the cover crops, narbon vetch (Vicia narbonensis), oat (Avena sativa), forage radish (Raphanus sativus), on weed suppression and soil nitrogen was studied in field conditions overwinter. The impact of their residues on the productivity of a subsequent corn crop was followed in the summer of the same year. Between midNovember and March oat produced, on a dry weight basis, $915 \mathrm{~g} \mathrm{~m}^{-2}$ against $402 \mathrm{~g} \mathrm{~m}^{-2}$ for narbon vetch and $292 \mathrm{~g} \mathrm{~m}^{-2}$ for radish. Consequently, weeds were suppressed best in the presence of oat. Narbon vetch was less effective than radish in controlling weeds, as it was slower to get established. In terms of mineral nitrogen, soils occupied by radish (13.1 $\mathrm{mg} \mathrm{kg}^{-1}$ soil) presented smaller concentrations of ammonium-N than those by vetch (18.7 $\mathrm{mg} \mathrm{kg}^{-1}$ soil) and the control (19.7 $\mathrm{mg} \mathrm{kg}^{-1}$ soil). Following the overwinter cover crops, plots were split into one half where roots only were incorporated, and another half receiving whole plants. Residues of whole plants promoted higher production of corn in the booting and flowering stages, as compared to roots only. At the $50 \%$ dough stage, the highest dry matter yield was $7.6 \mathrm{Mg} \mathrm{ha}^{-1}$ after narbon vetch. Corn yield was the smallest after oat, due to $N$ immobilization. This was demonstrated, using the litter bag technique, when oat residues $\left(15.6 \mathrm{~g} \mathrm{~N} \mathrm{~kg}^{-1}\right)$ lost $31 \%$ of their $\mathrm{N}$ against $66 \%$ for radish residues $\left(21.1 \mathrm{~g} \mathrm{~N} \mathrm{~kg}^{-1}\right)$. For an effective control of weeds and
\end{abstract}

http://dx.doi.org/10.22453/LSJ-020.1.089-103 National Council for Scientific Research - Lebanon 2018๔ 1sj.cnrs.edu.lb/vol-20-no-1-2019/ 
nutrient recycling a cover crop, such as oat, is most efficient. In this case, the succeeding summer crop needs to receive some extra nitrogen.

Key words: soil ammonium nitrogen, weed suppression, forage radish, summer corn, cover crop residues.

\section{INTRODUCTION}

Conventional growers have been slow to adopt cover crops in crop rotations. A renewed interest for including them was found among organic growers (Lawson 2010) and those who practice conservation agriculture. Many benefits have been associated with the use of cover crops. They reduced soil erosion and runoff, improved nitrogen cycling, weed and pest control, enhanced soil quality and increased yields (Kaspar and Singer 2011).

Cover crops are expected to increase plant water use and infiltration, which reduces the volume of runoff (Baldwin and Creamer 2006) as well as the sediment detachment and transport (Kaspar and Singer 2011). In Andalusian olive groves, white mustard (Sinapis alba) was more efficient than common vetch (Vicia sativa) and bitter vetch (Vicia ervilia) in reducing soil erosion (Repullo-Rubérriz de Torres 2014). Elsewhere, the presence of cereal rye or triticale, as cover crops, greatly reduced the runoff losses from Californian vineyards (Smith et al. 2008).

At the level of nutrient cycling, cover crops can be utilized to manage nitrogen by alternating $\mathrm{N}$ cycling and availability. Grown during fallow periods, they change the annual patterns of $\mathrm{N}$ uptake and mineralization, reduce downward movement of nitrate, and retrieve it from deep soil layers (Kaspar and Singer 2011). Cover crops extend the period of active $\mathrm{N}$ and water uptake to periods of the year when the cash crops are not present (Kladivko et al. 2004). Reductions in nitrate leaching losses were the highest with the non-legumes, with $65-70 \%$ reduction in $\mathrm{N}$ leaching by rye (Secale cereale) in California (Kaspar and Singer 2011). Further, durum wheat (Triticum durum) resulted in greater $\mathrm{N}$ retention compared to common vetch in Sicilian vineyards (Novara et al. 2013).

The ability of cover crops to control pests and weeds is highly relevant to farmers aiming to reduce tillage. Cover crops may not affect the emergence of weeds, but they can reduce weed biomass and weed seed production (O'Reilly 2009). Mechanisms such as smothering, shading, competition for nutrients, as well as allelopathy, may explain some of the observed effects (Baldwin and Creamer 2006). In southern Ontario, Canada, oilseed radish was more efficient than oat and cereal rye in controlling fall weeds (O'Reilly et al. 2011). In Michigan, an extensive study of cover crops in organic bean indicated that crops that contribute significantly to soil nitrogen may also stimulate weed emergence and growth (Hill et al. 2016). Cover crops may enhance the soil biological quality by promoting the build-up of soil organic matter. In a 
5-year-trial in Californian vineyards, cereal rye increased significantly the carbon in soil microbial biomass (Smith et al. 2008).

The choice of suitable cover crops takes into consideration the pedo-climatic factors, as well as the agronomic aspects. Many legume cover crops showed good results in Mediterranean climates. Alfalfa (Medicago sativa) is drought-tolerant and a superior $\mathrm{N}$ fixer, but it requires quite fertile soils (Schonbeck and Morse 2006). Faba bean (Vicia faba), tested in California and Italy, had a very good nitrogen fixing ability, its shallow root system aided the biological activity (Thomas and Archambeaud 2012). Common vetch (Vicia sativa) was tested in soils with $\mathrm{pH}$ between 6 and 7 (Frame 2004). A good $\mathrm{N}$ fixer, it provided green manure and had a low competition with the main crop (Pardini et al. 2002) but may not perform well in alkaline soils. An alternative vetch, narbon vetch (Vicia narbonensis) was tested on a large scale in southwestern Australia as a forage crop (Seymour 2006) and in southern Spain as a grain legume (Nadal and Moreno 2007). Among the non-legumes dicots, white mustard showed good results in Mediterranean climates (Repullo-Rubérriz de Torres 2014) and forage radish (Raphanus sativus var. longipinnatus) was promoted in Mid-Atlantic coastal regions of the USA. Planted early, it can grow rapidly, absorb soil nitrogen and suppress weeds (Lawley et al. 2012).

In Mediterranean Lebanon, common vetch was planted by selected olive growers, which lead to an improved soil fertility and tree vigor, as well as an increase in yield (GIZ 2013). In order to provide local references and test the performance of novel cover crops and their ability to compete with weeds overwinter, a trial was conducted in coastal Lebanon. Oat and forage radish as well as narbon vetch were tested as cover crops. The work focused on the ability of rainfed cover crops to build dry matter, suppress weeds, and absorb soil mineral nitrogen when grown from late autumn to midspring in coastal sub-humid conditions.

\section{MATERIALS AND METHODS}

\section{Sites description}

The experiment was carried out in Lebaa, south of Lebanon $\left(33^{\circ} 32^{\prime} 56^{\prime \prime} \mathrm{N}\right.$; $35^{\circ}$ $27^{\prime} 10^{\prime \prime} \mathrm{E} ; 360 \mathrm{~m}$ asl), at the Lebanese Agricultural Research Institute. Rainfall, as obtained from the local weather station, reached $653.8 \mathrm{~mm}$ between November $14^{\text {th }}$ 2015 and March $9^{\text {th }} 2016$, and decreased to $215 \mathrm{~mm}$ between March $9^{\text {th }}$ and August $3^{\text {rd }}$ (Figure 1). The soil presented a silty clay loam texture, an average of $15 \mathrm{~g} \mathrm{~kg}^{-1}$ of OC, a $\mathrm{pH}$ of 7.75 and $590 \mathrm{~g} \mathrm{~kg}^{-1}$ of calcium carbonate. 


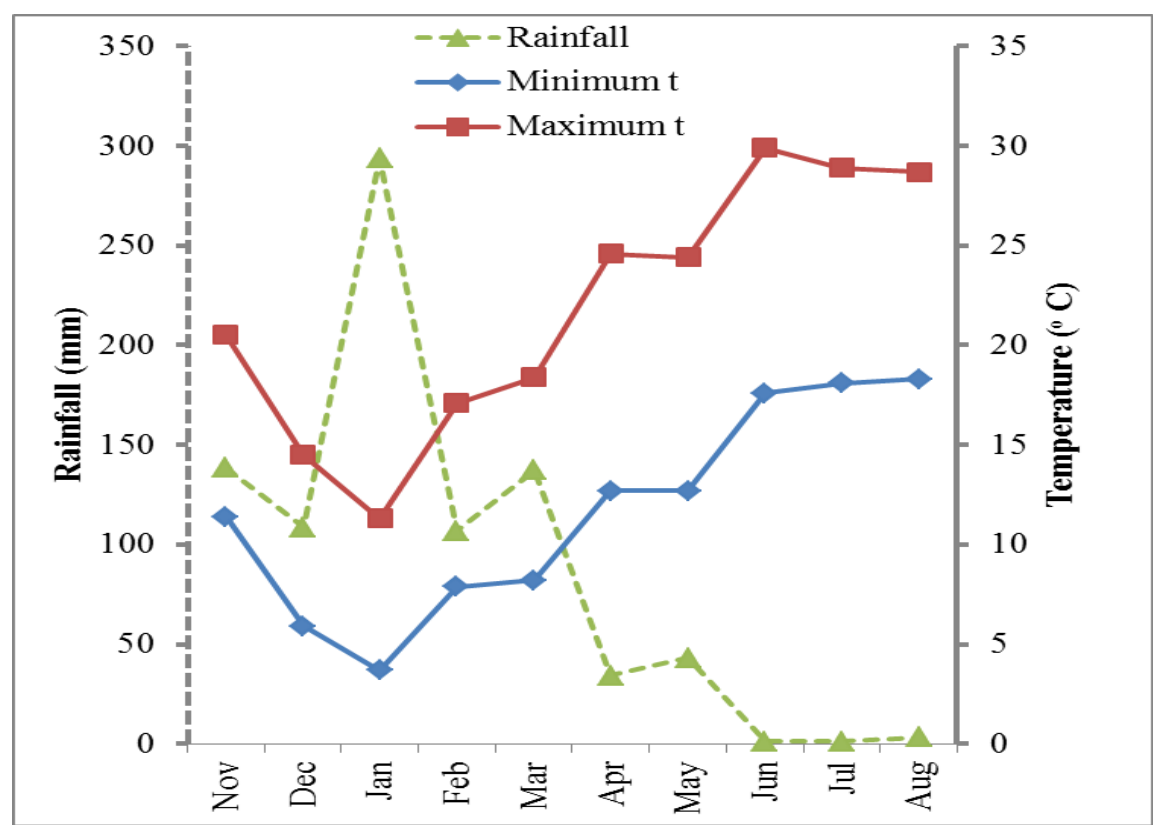

Figure 1. The rainfall, minimum and maximum temperatures between November 2015 and August 2016 as recorded in Lebaa meteorological station.

\section{Experimental set-ups}

Four treatments (oat, radish, narbon vetch and unplanted control) were included, in four replicates, distributed in a completely randomized block design. Seeds of oat (Avena sativa), forage radish (Raphanus sativus) and narbon vetch (Vicia narbonensis) were sown by broadcasting on 14 November 2015. Neither fertilizers nor herbicides were applied before planting or during the growth cycle, except for the insecticide Chlorpyrifos against ants.

Cover crops were terminated mechanically on March $29^{\text {th }}$. Each plot $(4 \mathrm{~m} \times 2.5$ m) was divided in two halves: one half where only roots were kept, the other half where the whole plant was incorporated. Shredded residues were left on the soil surface till April $18^{\text {th }}$, when they were incorporated superficially. On April $29^{\text {th }}$, seeds of corn (Zea mays) variety Calcio (Maisadour semences) were planted in the experimental plots. The sowing was done manually $(0.40 \mathrm{~m} \times 0.25 \mathrm{~m})$ at a density of 10 plants $\mathrm{m}^{-2}$. Drip irrigation system was installed and the crop was irrigated twice weekly from a local well. The crop received a total of $268 \mathrm{~mm}$ of irrigation water.

\section{Sampling of plants and soil}

Three quadrats $(0.50 \mathrm{~m} \times 0.50 \mathrm{~m})$ of weeds were sampled per plot on January $13^{\text {th }}$. Later, on February $13^{\text {th }}$ and March $9^{\text {th }}$ (Table 1), one quadrat was collected from each plot. Cover crops were then separated from weeds. These were identified fresh, 
then dried at $70{ }^{\circ} \mathrm{C}$. Similarly, the biomass of cover crops was recorded on a dry weight basis.

Corn samples were collected at three growth stages (Table 1), by removing four neighboring plants from each plot. Fresh plants were cut into small pieces, weighed, and then dried at $70{ }^{\circ} \mathrm{C}$. To evaluate the status of soil mineral nitrogen, soil samples were collected on two dates at two soil depths (Table 1).

Table 1. Sampling dates of plants, crops and weeds, and soil between November 2015 and August 2016.

\begin{tabular}{|c|c|c|c|}
\hline & \multicolumn{2}{|c|}{ Crop } \\
\hline & & $\begin{array}{c}\text { Cover crops } \\
\text { Nov 2015-March } 2016\end{array}$ & $\begin{array}{c}\text { Corn } \\
\text { April-August } 2016\end{array}$ \\
\hline \multirow{3}{*}{ 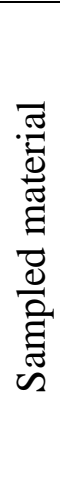 } & Crops & $\begin{array}{l}\text { February } 13 \\
\text { March } 9\end{array}$ & $\begin{array}{c}\text { June } 30 \text { (booting stage) } \\
\text { July } 19 \text { (flowering stage) } \\
\text { August } 3(50 \% \text { dough } \\
\text { stage) }\end{array}$ \\
\hline & Weeds & $\begin{array}{c}\text { January } 16, \text { February } \\
13 \\
\text { March } 9\end{array}$ & $\begin{array}{c}\text { May 14, June } 30 \\
\text { July } 26\end{array}$ \\
\hline & $\begin{array}{l}\text { Soil }(0-0.2 \mathrm{~m} ; 0.2-0.4 \\
\mathrm{m})\end{array}$ & $\begin{array}{l}\text { February } 13, \text { March } 29 \\
\text { (control, narbon vetch, } \\
\text { radish) }\end{array}$ & - \\
\hline
\end{tabular}

\section{Study of litter bags}

Litter bag test is a very common method to study litter decomposition. A known quantity of shredded cover crops is placed into a mesh bag, and the bag is then buried. The mesh bags allow smaller insects and microorganisms to access the shredded plants (Shi 2013). Mesh bags were made from a non-degradable polyethylene (hole size 0.9 $\mathrm{mm})$. Each bag was filled with air-dried oat $\left(7 \mathrm{~g} \mathrm{bag}^{-1}\right)$ or radish $\left(8 \mathrm{~g} \mathrm{bag}^{-1}\right)$. Each bag was folded then stapled. Bags were buried to a depth of $10 \mathrm{~cm}$ in each corresponding plot, on April $18^{\text {th }}$. Three to four bags were extracted from each plot on April $28^{\text {th }}$, July $19^{\text {th }}$ and August $3^{\text {rd }}$.

\section{Analytical procedures}

Plant samples of March $9^{\text {th }}$ and August $3^{\text {rd }}$ were analyzed for total (Kjeldahl) nitrogen. A subsample $(\sim 0.5 \mathrm{~g})$ of ground plant material $(<1 \mathrm{~mm})$ was digested in the presence of $10 \mathrm{~mL}$ of concentrated sulfuric acid $(10 \mathrm{~mL})$ and a catalyst $(3.35 \mathrm{~g}$ of $\mathrm{K}_{2} \mathrm{SO}_{4}+\mathrm{CuSO}_{4} .5 \mathrm{H}_{2} \mathrm{O}+\mathrm{Se}$ ) until complete digestion. The digest was steam distillated in 
the presence of sodium hydroxide. The distillate was titrated with hydrochloric acid, in the presence of Tashiro indicator (Estefan et al. 2013).

For the soil ammonium nitrogen, $10 \mathrm{~g}$ of air-dried samples $(<2 \mathrm{~mm})$ were shaken with $50 \mathrm{~mL}$ of $\mathrm{KCl}(1 \mathrm{M})$ for 30 minutes then filtered (Whatman $\mathrm{N}^{\circ} 40$ ). Ammonium was determined after distillation with $\mathrm{MgO}$, followed by the titration of the distillate with hydrochloric acid. After cooling to room temperature, the nitrate was determined in the presence of Devarda alloy. The effects of blocks and treatments were analyzed using the ANOVA statistical analysis (Sigmastat version 3.5).

Extracted litter bags were analyzed for nutrient (N, P and K) contents. Procedure for phosphorus and potassium consisted of ashing $0.5 \mathrm{~g}$ of dry and ground material in crucibles at $550{ }^{\circ} \mathrm{C}$. The cooled ash was dissolved in two portions of $5 \mathrm{~mL}$ of $\mathrm{HCl}(2 \mathrm{~N})$ then the volume was adjusted to $50 \mathrm{~mL}$ before filtering (Whatman $\mathrm{N}^{\circ} 42$ ). Aliquots were analyzed for $\mathrm{P}$ by colorimetry and for $\mathrm{K}$ by flame photometry (Estefan et al. 2013).

\section{RESULTS AND DISCUSSION}

\section{Cover crop production}

Oat showed the highest production, followed by radish and narbon vetch (Table 2). Narbon vetch was poorly competitive at first, despite a high planting density of 150 $\mathrm{kg} \mathrm{ha}^{-1}$. On March 9, the cereal continued to perform better than both dicots species (Table 2). Forage radish, a novel crop to Mediterranean Lebanon, did not produce as well as in the humid temperate regions.

Table 2. Biomass $\left(\mathrm{g} \mathrm{m}^{-2}\right)$ and nitrogen yields $\left(\mathrm{g} \mathrm{m}^{-2}\right)$ of three cover crops (oat, radish and narbon vetch) and weeds in comparison to the unplanted control.

\begin{tabular}{|c|c|c|c|c|c|c|c|c|c|}
\hline \multirow{3}{*}{ Treatment } & \multirow{2}{*}{\multicolumn{3}{|c|}{$\frac{\text { February } 13}{\text { Biomass }\left(\mathrm{g} \mathrm{m}^{-2}\right)}$}} & \multicolumn{6}{|c|}{ March 9} \\
\hline & & & & \multicolumn{3}{|c|}{ Biomass $\left(\mathrm{g} \mathrm{m}^{-2}\right)$} & \multicolumn{3}{|c|}{$\mathrm{N}$ yield $\left(\mathrm{g} \mathrm{m}^{-2}\right)$} \\
\hline & Crop & Weeds & Sum & Crop & Weeds & Sum & Crop & Weeds & Sum \\
\hline Control & - & $247^{\mathrm{A}}$ & 247 & - & $357^{\mathrm{A}}$ & $357^{B}$ & - & $5.22^{\mathrm{a}}$ & $5.22^{b}$ \\
\hline Oat & $387^{\mathrm{A}}$ & $52^{\mathrm{B}}$ & 439 & $917^{\mathrm{A}}$ & $53^{\mathrm{B}}$ & $\mathbf{9 7 2}^{\mathrm{A}}$ & 14.8 & $0.71^{\mathrm{b}}$ & $15.58^{\mathrm{ab}}$ \\
\hline Radish & $203^{\mathrm{AB}}$ & $80^{\mathrm{B}}$ & 283 & $292^{\mathrm{B}}$ & $238^{\mathrm{AB}}$ & $\mathbf{5 3 1}^{\mathrm{B}}$ & 6.79 & $4.23^{\mathrm{ab}}$ & $11.02^{\mathrm{ab}}$ \\
\hline N. vetch & $165^{\mathrm{B}}$ & $252^{\mathrm{A}}$ & 417 & $402^{\mathrm{B}}$ & $306^{\mathrm{A}}$ & $\mathbf{7 0 8}^{\mathrm{A}}$ & 14.1 & $4.42^{\mathrm{ab}}$ & $18.56^{\mathrm{a}}$ \\
\hline
\end{tabular}

Within one column, values followed by the same letter are not significantly different $(p<0.05)$. 
Nitrogen uptake was studied for each cover crop. The $\mathrm{N}$ content of the upper parts of narbon vetch $\left(28.9 \mathrm{~g} \mathrm{~N} \mathrm{~kg}^{-1}\right)$ was significantly higher than oat $\left(15.6 \mathrm{~g} \mathrm{~N} \mathrm{~kg}^{-1}\right)$, while that of radish $\left(21.1 \mathrm{~g} \mathrm{~N} \mathrm{~kg}^{-1}\right)$ occupied an intermediate position. But the $\mathrm{N}$ yield of the legume was not high (Table 2), because of its moderate dry matter production. For this, the summed $\mathrm{N}$ yields (Table 2) showed no significant differences between the legume and the two non-legumes.

\section{Cover crops and soil mineral nitrogen}

The presence of living plants during fallow periods can reduce leaching losses of nitrate by reducing its concentration in the soil solution. The evaluation of soil mineral nitrogen gave very small concentrations for nitrate-nitrogen, for this, only ammoniumnitrogen will be presented. The ammonium concentrations were different between soil depths, on February $13^{\text {th }}$ but not in late March (Table 3) possibly because of the higher uptake of nitrogen by superficial roots.

When each cover crop was taken separately, radish caused a decrease in the mineral nitrogen of the upper soil. The legume used less of the soil ammonium, in the absence of a significant difference between the two dates (Table 3). This could be due to some $\mathrm{N}$ fixation, especially in late spring, leading to a reduced uptake of soil mineral nitrogen. At the end of the trial, forage radish removed more ammonium nitrogen than the narbon vetch or the control (Table 3). This indicates the suitability of non-legumes, in mild winter conditions of sub-humid Mediterranean, for recycling soil mineral nitrogen.

Table 3. Ammonium-nitrogen ( $\mathrm{mg} \mathrm{kg}^{-1}$ soil) in two soil depths as affected by the plant cover on February 13 and March 29 of the 2016 season.

\begin{tabular}{|c|c|c|c|c|c|c|}
\hline \multirow{3}{*}{ Treatment } & \multicolumn{3}{|c|}{ February 13} & \multicolumn{3}{|c|}{ March 29} \\
\hline & \multicolumn{2}{|c|}{ Soil depth (m) } & \multirow[b]{2}{*}{ Mean } & \multicolumn{2}{|c|}{ Soil depth (m) } & \multirow[b]{2}{*}{ Mean } \\
\hline & $0-0.2$ & $0.2-0.4$ & & $0-0.2$ & $0.2-0.4$ & \\
\hline Unplanted & 23.3 & 16.4 & 19.8 & 19.2 & 20.2 & $19.7^{\mathrm{a}}$ \\
\hline Narbon vetch & 28.8 & 17.4 & 23.1 & 19.9 & 17.5 & $18.7^{\mathrm{a}}$ \\
\hline Radish & 27.4 & 22.6 & 25.0 & 10.8 & 14.6 & $13.1^{\mathrm{b}}$ \\
\hline Mean & $26.5^{¥ ¥}$ & $18.8^{¥}$ & & $16.6^{\alpha}$ & $17.7^{\infty}$ & \\
\hline
\end{tabular}

Values followed by different characters (within one row) and by different letters (within one column) are significantly different at the $5 \%$ level.

\section{Decomposition of cover crop residues}

Following the termination of the cover crop, the residual biomass was left to decompose in-situ. After 10 days of incubation in litter bags, radish residues lost $64.4 \%$ of their mass against and $41.9 \%$ for oat. This rapid decrease was probably due to the activity of microorganisms on the soluble fractions of the residues. Between day-10 and 
day-93 of incubation (August $3^{\text {rd }}$ ), the mass loss represented $19 \%$ of the original material for radish and $38 \%$ for oat. Over all the incubation period, radish mass decreased by $83 \%$ and oat by $80 \%$. The residues of the cereal decomposed more slowly but the final loss was very close, due to the sustained microbial activity under the irrigated conditions of the trial.

Next to the mass loss, the changes of nutrients were also determined. The nitrogen and potassium contents were similar between cover crops at the onset of the trial (Figure 2). During the first 10 days of incubation, oat residues lost $31.4 \%$ of N, and $45.0 \%$ of $\mathrm{K}$. Nutrients released from radish residues were significantly higher for nitrogen $(65.7 \%$ of initial $\mathrm{N}$ ) and potassium $(67.2 \%$ of initial $\mathrm{K})$. The values for phosphorus showed no difference between cover crops at the beginning. Losses of $\mathrm{P}$ reached some $40.9 \%$ after 10 days of incubation (data not shown). Based on the $\mathrm{N}$ yields (Table 2) and on this loss, the $\mathrm{N}$ mineralized, exclusive of weeds, represented

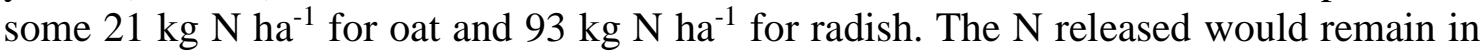
the soil, in the absence of a positive water balance during mid-spring (Figure 1).

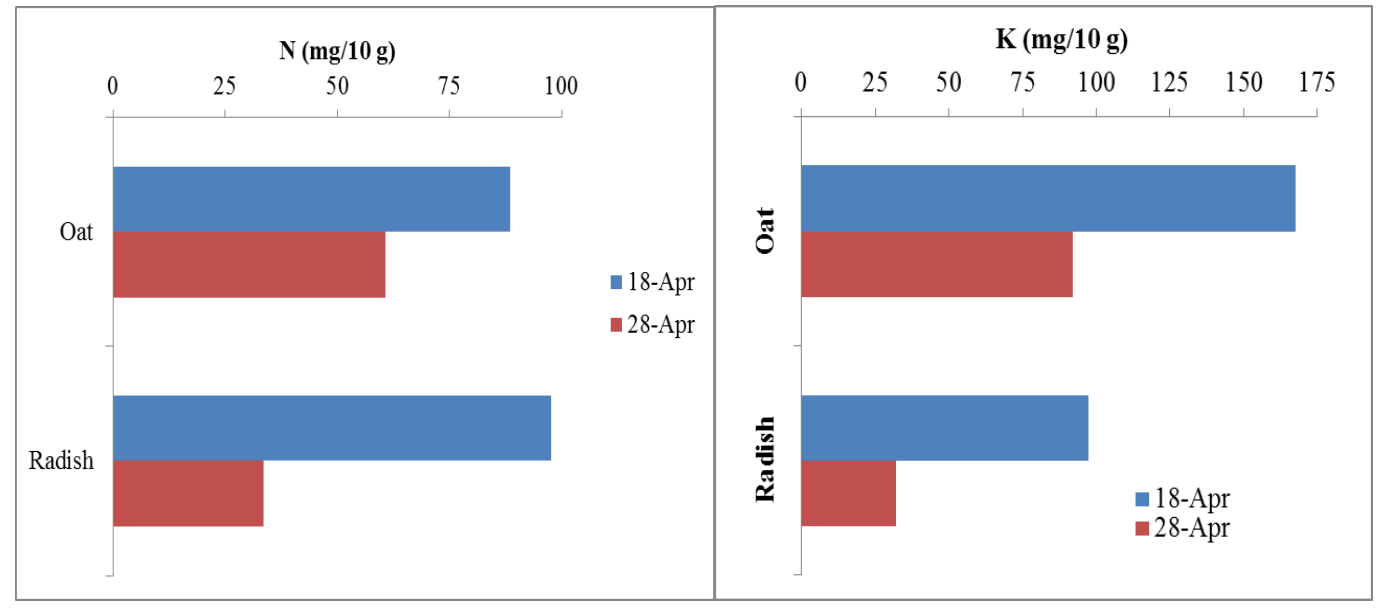

Figure 2. Nitrogen and potassium lost from residues of oat and radish after 10 days of incubation in-situ in litter bags.

\section{Performance of corn}

The dry weights of corn were determined at the booting (June $30^{\text {th }}$ ), flowering (July $19^{\text {th }}$ ) and $50 \%$ dough (August $3^{\text {rd }}$ ) stages. At the booting and flowering stages, the half-plots where whole plants were incorporated produced higher dry matter, as compared to roots only (Figure 3). The growth of corn was faster and stronger indicating that nutrients were more available from shoots. As nitrogen became limited, the difference between biomasses disappeared at the 50\% dough stage (Figure 3). At this stage, corn after oat $\left(396 \mathrm{~g} \mathrm{~m}^{-2}\right)$ produced the least, followed by the control $(528 \mathrm{~g}$ $\left.\mathrm{m}^{-2}\right)$, radish $\left(700 \mathrm{~g} \mathrm{~m}^{-2}\right)$ and narbon vetch $\left(761 \mathrm{~g} \mathrm{~m}^{-2}\right)$. When compared two by two, a significant difference was obtained within the pairs oat/radish, and oat/narbon vetch. 
If the biomasses of cover crops did not a significant difference, nitrogen yields could be split into two groups. The first formed by vetch and radish against the control and oat. $\mathrm{N}$ uptake of corn after vetch $\left(6.55 \mathrm{~g} \mathrm{~m}^{-2}\right)$ was not statistically different from radish $\left(5.32 \mathrm{~g} \mathrm{~m}^{-2}\right)$, but significantly higher than oat $\left(3.22 \mathrm{~g} \mathrm{~m}^{-2}\right)$ and the control $(3.74 \mathrm{~g}$ $\mathrm{m}^{-2}$ ). Narbon vetch provided the highest amount of plant available $\mathrm{N}$; some $28 \mathrm{~kg} \mathrm{~N}^{-1}$ above the unplanted control, against $16 \mathrm{~kg} \mathrm{~N}^{-1}$ for radish. Oat was effective in preventing mineral $\mathrm{N}$ leaching during winter, but caused a reduced $\mathrm{N}$ yield of corn. There was a shortage of nitrogen, at a later growth stage, in the absence of any input of external nitrogen forms. in this case the largest $\mathrm{N}$ uptake was equal to $90 \mathrm{~kg} \mathrm{~N} \mathrm{ha}^{-1}$ for narbon vetch in the whole plant treatment.

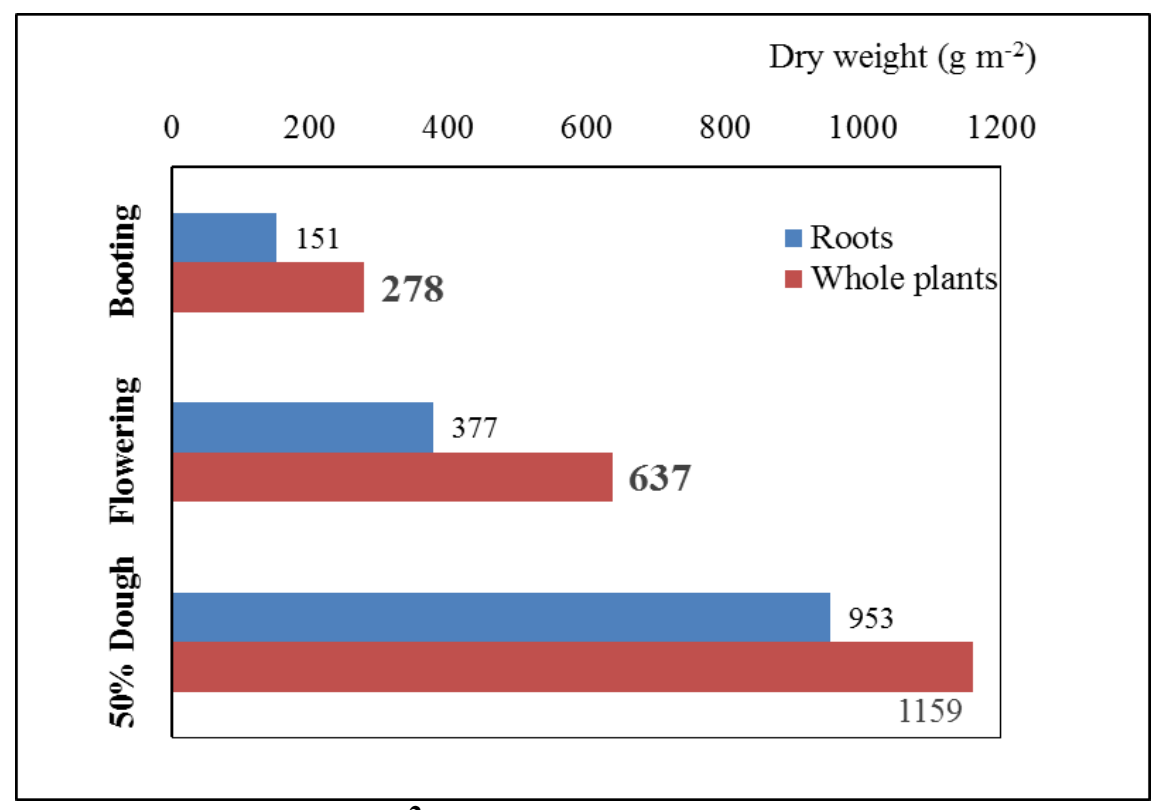

Figure 3. Corn biomass $\left(\mathrm{g} \mathrm{m}^{-2}\right)$ at booting, flowering and $50 \%$ dough stages, as affected by the incorporation of whole cover crops or the roots only.

At booting and flowering stages, Whole plants (bold) are significantly different from the Roots treatment.

\section{Weed suppression}

Weeds biomass increased steadily, reaching $357 \mathrm{~g} \mathrm{~m}^{-2}$ in the control in March 2016 (Table 2). In the early winter 2016, Rapistrum rugosum (turnip weed) dominated (44\% of biomass) in the control. Later on, its level decreased to $37 \%$ then to $27 \%$. In terms of weed biomass, Fumaria sp., from the Papaveraceae family, ranked second throughout the season. Anagallis sp., from the Primulaceae family, increased from $6.4 \%$, to $19 \%$ then to $16 \%$, during the successive sampling dates.

Cover crops can reduce weed density and biomass through mechanisms such as smothering, shading and competition for nutrients. Among the cover crops, oat was best 
in controlling weeds and narbon vetch was worst, in February and March (Table 2). Its reduced ground coverage did not allow it to compete with weeds. Despite a high planting density (150 kg ha ${ }^{-1}$ ), narbon vetch was not efficient in suppressing weeds. Radish occupied an intermediate position between the cereal, on one side, and the narbon vetch and unplanted control, on the other.

In this work, the weed biomass was analyzed separately for each residue. Results indicated a negative effect of the oat residues on the overall weed growth on May $14^{\text {th }}$ (Table 5). Radish residues were similar to the unplanted control, and to narbon vetch. Then, on June $30^{\text {th }}$ the difference between weed biomass was not visible anymore. Finally on July $26^{\text {th }}$, weeds had the highest biomass with a significant difference between roots and whole plants.

Table 5. Effects of the roots and the whole plant of previous cover crops on the biomass of weeds $\left(\mathrm{g} \mathrm{m}^{-2}\right)$ found in corn planted late April and harvested on August $3^{\text {rd }}$.

\begin{tabular}{|c|c|c|c|c|c|c|}
\hline \multirow[b]{2}{*}{ Date } & \multirow[b]{2}{*}{$\begin{array}{c}\text { Part } \\
\text { incorporated }\end{array}$} & \multicolumn{4}{|c|}{ Previous cover crop } & \multirow[b]{2}{*}{ Mean } \\
\hline & & Radish & $\begin{array}{c}\text { Narbon } \\
\text { vetch }\end{array}$ & Oat & Control & \\
\hline \multirow{3}{*}{ May 14} & Roots & 9.12 & 7.20 & 3.73 & 5.11 & 6.29 \\
\hline & Whole plant & 9.22 & 6.27 & 2.31 & 9.43 & 6.81 \\
\hline & Mean & $9.18^{\mathrm{a}}$ & $6.73^{\mathrm{ab}}$ & $3.02^{b}$ & $7.27^{\mathrm{a}}$ & \\
\hline \multirow{3}{*}{ June 30} & Roots & 14.61 & 26.14 & 15.06 & 22.06 & 19.47 \\
\hline & Whole plant & 18.06 & 10.44 & 11.78 & 17.92 & 14.54 \\
\hline & Mean & 16.33 & 18.29 & 13.42 & 19.99 & \\
\hline \multirow{3}{*}{ July 26} & Roots & 30.89 & 25.42 & 23.83 & 28.20 & $27.09^{A}$ \\
\hline & Whole plant & 17.48 & 15.98 & 13.06 & 13.78 & $15.07^{\mathrm{B}}$ \\
\hline & Mean & 24.18 & 20.7 & 18.44 & 21.00 & \\
\hline
\end{tabular}

Values followed by the same small letter (within one row) and by the same capital letter (within one column) are not significantly different at the 5\% level. 


\section{DISCUSSION}

\section{Biomass of cover crops and weed suppression}

The ability of cover crops to control pests and weeds is highly relevant to farmers aiming to reduce tillage. To adequately suppress weeds, cover crops must be able to produce biomass and provide ground coverage, early in the growing season (Yeganehpoor et al. 2014; Sanchez 2016) which could be obtained through high seeding rates. The best establishment was for oat, while narbon vetch was poorly competitive at first, despite a high planting density of $150 \mathrm{~kg} \mathrm{ha}^{-1}$. The planting rate adopted was much higher than that recommended for grain production $\left(75-100 \mathrm{~kg} \mathrm{ha}^{-1}\right)$ in southwestern Australia (Seymour 2006) under similar climatic condtions. Forage radish, a novel crop to Mediterranean Lebanon, did not produce as well as in the humid temperate regions, where a biomass of $9 \mathrm{Mg} \mathrm{ha}^{-1}$ could be expected (Weil et al. 2009).

Grown during fallow periods, cover crops change the annual patterns of $\mathrm{N}$ uptake and mineralization (Kaspar and Singer 2011). The nitrogen content of narbon vetch compared favorably with values found in Sicilian vineyards, when common vetch presented a $\mathrm{N}$ content of $28 \mathrm{~g} \mathrm{~N} \mathrm{~kg}^{-1}$ (Novara et al. 2013). But the $\mathrm{N}$ yield was not high, because of its moderate dry matter production.

Cover crops can reduce weed density and biomass through mechanisms such as smothering, shading and competition for nutrients. In addition, decomposing residues may have an allelophatic toxic effect on weed seed germination and seedling growth (Baldwin and Creamer 2006; Shakibafar et al. 2016). Plants of the Brassicaceae family were able to suppress the majority of weeds, compared to a bare fallow (Snapp et al. 2005), yet in this case, radish was not able to suppress the invasive turnip weed, belonging to the same botanical family.

\section{Residues and summer crop}

Following the termination of the cover crop, the residual biomass was left to decompose in-situ. The second stage of decomposition was much slower, because the remains consisted of very large and complex molecules such as cellulose (Shi 2013). Over all the incubation period, radish mass decreased by $83 \%$ and oat by $80 \%$. Next to the mass loss, the decrease in $\mathrm{N}$ contents indicated an active mineralization (Sanchez 2010). This was observed in alfalfa shoots $\left(33.6 \mathrm{~g} \mathrm{~N} \mathrm{~kg}^{-1}\right)$ that lost $60 \%$ of their $\mathrm{N}$, from mid-november till mid-december in the same soil (Al Chami et al. 2015). The faster release of $\mathrm{N}$, in this study, could be linked to the warmer temperatures in April as compared to those of December.

Despite the nutrients released from residues, the highest yield of corn ( $c a 7.60$ $\mathrm{Mg} \mathrm{ha}^{-1}$ ) does not compare favorably with a dry matter production close to $10 \mathrm{Mg} \mathrm{ha}^{-1}$ (FAO 2006) reported in the litterature. Oat was effective in preventing mineral $\mathrm{N}$ 
leaching during winter, but caused a reduced $\mathrm{N}$ yield of corn. The negative effect can be explained by $\mathrm{N}$ immobilization due to its high C:N ratio (Kramberger et al. 2009). There was a shortage of nitrogen, at a later growth stage, in the absence of any input of external nitrogen forms. The $\mathrm{N}$ uptake or removal of forage corn reached $225 \mathrm{~kg} \mathrm{~N} \mathrm{ha}^{-1}$ for a yield of $10 \mathrm{Mg} \mathrm{ha}^{-1}$ (FAO 2006), while in this case the largest $\mathrm{N}$ uptake was equal to $90 \mathrm{~kg} \mathrm{~N} \mathrm{ha}^{-1}$ for narbon vetch in the whole plant treatment.

Weeds are one of the greatest limiting factors to efficient crop production. Corn fields may be particularly rich in weed species, as 25 to 30 annual and perennial weed species were found in corn fields (Yeganehpoor et al. 2015). In this work, the weed biomass analyzed separately for each residue, indicated a negative effect of oat on weed growth. This was probably due the effect of the tops releasing allelochemicals, suppressing weeds. Such an effect remains a hypothetical explanation and requires further demonstration. Elsewhere, residues of wheat, rye, and triticale delayed the emergence of pigweed (Amaranthus L. sp) and foxtail (Setaria sp) in soybean (McDonald 2007).

\section{CONCLUSIONS}

The study compared between narbon vetch, forage radish and oat as overwinter cover crops. Oat had the highest biomass production, while narbon vetch produced a modest coverage despite its high sowing density ( radish, tested for the first time in Mediterranean conditions, was not as productive as under temperate conditions. The early ground coverage by oat was favorable in terms of the control of weeds. In narbon vetch, the weed biomass was similar to the unplanted control.

High biomass productivity may also be an important factor in the trapping of soil mineral nitrogen. Nitrogen content was higher in narbon vetch, as compared to oat. But nitrogen yields $\left(\mathrm{g} \mathrm{m}^{-2}\right)$ were similar between both crops, due to smaller biomass in narbon vetch. When adding the $\mathrm{N}$ yield of the cover crop and the weeds, the narbon vetch presented higher $\mathrm{N}$ yield than the control. Still, the nitrogen yield of the legume was not different from the non-legumes. Mineral nitrogen was evaluated as a further indication of the effects of cover crops on soil nitrogen. Between mid-February and the end of March, soil ammonium decreased in the upper soil (0-0.20 m depth), due to its uptake by plants and to the nitrification. But at 0.2-0.4 $\mathrm{m}$ depth, ammonium was close between the two dates. Narbon vetch enhanced the amount of ammonium nitrogen in the soil, but forage radish exhausted it.

In late March, plots were split into two, with one of them receiving only the roots of cover crops, and the other the whole plants (shoots plus roots). Forage corn, planted late April, presented higher production in the booting and flowering stages, in the halves with whole plants, as compared to roots only. At the 50\% dough stage, the summer crop was short in $\mathrm{N}$ as the previous cover could not provide all of its needs. The best dry matter yield was 7.6 tons ha $^{-1}$ after narbon vetch. When compared by pairs, it 
was found that after oat, the yield was the smallest, due to some $\mathrm{N}$ immobilization by the residues of the cereal. As an overwinter cover crop, oat was most efficient in terms of biomass production and weed suppression. It could be used in cultures aiming to reduce tillage and control weed growth. Residues of cover crops, and in the absence of inputs of fertilizers, could not promote the full development of a succeeding summer crop. Nitrogen was a limiting factor. A combination of oat with narbon vetch or another vetch, such as common vetch, need to be investigated as an overwinter cover crop in terms of soil nitrogen recycling and weed control.

\section{ACKNOWLEDGEMENTS}

Authors are grateful to the staff of the Lebanese Agricultural Research Institute, in Lebaa station, and to engineer Elissar Touma from the Faculty of Agricultural Sciences in the Lebanese University, for technical support.

\section{REFERENCES}

Al Chami Z., S. Bou Zein-Eldeen, L. Al Bitar, and Atallah T. 2016. Decomposition of olive-mill waste compost, goat manure and Medicago sativa in Lebanese soils as measured using the litterbag technique. Soil Research, 54: 191-199.

Al-Ouda A. S. and Steiner K.. 2011. Conservation Agriculture. Training manual for extension agents and farmers. ACSAD and FAO, Damascus. $160 \mathrm{pp}$.

Baldwin K.R., and Creamer N.G.. 2006. Cover crops for organic farms. North Carolina cooperative extension services, NC State University 07/2006-BS. 22 pp.

Darby H., E. Cummings, S. Monahan, J. Post, and Zeigler S. 2014. Long season corn silage variety trial. University of Vermont Extension. 13 pages. http://www.uvm.edu/extension/cropsoil. Accessed in January 2018.

Dean J.E. and Weil R.R.. 2009. Brassica cover crops for nitrogen retention in the MidAtlantic coastal plain. Journal Environmental Quality, 38 (2): 520-528.

Estefan G., Sommer R. and Ryan J. 2013. Methods of soil, plant, and water analysis: A manual for the West Asia and North Africa. $3^{\text {rd }}$ Ed. ICARDA, Beirut, Lebanon, $243 \mathrm{pp}$.

Fageria, N.K., Baligar V.C., and Bailey B.A. 2005. Role of cover crops in improving soil and row crop productivity. Communications in Soil Science and Plant Analysis, 36: 2733-2757.

FAO. 2006. Near-East fertilizer use manual. Rome, 2006. 197 pp.

Ingels C.A., Bugg R.L., and Thomas F.L. 1998. Cover crop species and descriptions. Chapter 2. Pp 8-26, (http://www.ucanr.org/sites/intvit/files/24446.pdf accessed in Nov 2018).

Hill E.C., Renner K.A., Sprague C.L. and Davis A.S.. 2016. Cover crop impact on weed dynamics in an organic dry bean system. Weed Science, 64(2): 261-275. doi: http://dx.doi.org/10.1614/WS-D-15-00114.1

Kaspar T.C. and Singer J.W. 2011. The use of cover crops to manage soil. In: Soil Management: Building a Stable Base for Agriculture. Pp 321-334. Hatfield J.L. 
and T.J. Sauer (eds.). American Society of Agronomy and Soil Science Society of America. Wisconsin. doi:10.2136/2011.soilmanagement.c21.

Kladivko, E.J., J.R. Frankenberger, D.B. Jaynes, D.W. Meek, B.J. Jenkinson, and Fausey N.R. 2004. Nitrate leaching to subsurface drains as affected by drain spacing and changes in crop production system. Journal Environmental Quality, 33:1803-1813.

Kladivko, E. 2015. Cover Crops for Modern Cropping System. Managing cover crops. Purdue Department of Agronomy, Purdue Extension, p.3.

Lawley Y.E., J.R. Teasdale, and Weil R.R.. 2012. The mechanism for weed suppression by a forage radish cover crop. Agronomy Journal, 104 (1): 1-10.

Lawson A.J. 2010. Cover crops to enhance soil productivity in organic vegetable cropping systems. Degree of Masters of Science in Soil Science, Washington State University. 143 pp.

McDonald, P.B. 2007. Management of self-seeding winter cereal cover crops in a soybean-corn rotation. Degree of Master of Science, graduate faculty, Iowa State University. Chapter 2, p.5. (http://lib.dr.iastate.edu/rtd).

Mix K., Lopes V.L. and Rast W. 2012. Growing season expansion and related changes in monthly temperature and growing degree days in the Inter-Montane desert of the San Luis Valley, Colorado. Climatic Change, 114: 723-744.

Novara A., L. Gristina, F. Guaitoli, A. Santoro, and Cerd`a A. 2013. Managing soil nitrate with cover crops and buffer strips in Sicilian vineyards. Solid Earth, 4: 255-262.

O'Reilly K. 2009. Nitrogen cycling and weed dynamics in a pea-cover crop-sweet corn rotation. Degree of Master of Science, Faculty of Graduate Studies, University of Guelph, Canada. 147 pp.

O'Reilly K.A., D.E. Robinson, R.J. Vyn and van Eerd L.L. 2011. Weed populations, sweet corn yield, and economics following fall cover crops. Weed technology, 25 (3): 374-384. Accessed on March 30 2017.

Pardini A., Faiello C., Longhi F., Mancuso S., and Snowball R.. 2002. Cover crop species and their management in vineyards and olive groves. Advanced Horticultural Science, 16 (3-4): 225-234.

Qi Z. and Helmers M.J. 2010. Soil water dynamics under winter rye cover crop in central Iowa. Vadose Zone Journal, 9: 53-60.

Reddy, K.N., Zablotowicz R.M., Locke M.A., and Koger C.H. 2003. Cover crop, tillage, and herbicide effects on weeds, soil properties, microbial populations, and soybean yield. Weed Science, 51: 987-994.

Repullo-Ruibérriz de Torres M. A. (2014) Cover crops management as conservation system and improvement of soil quality and runoff water in the Andalusian olive grove. $\mathrm{PhD}$ thesis, Cordoba University. $112 \mathrm{pp}$.

Sanchez I.I. 2016. Evaluation of winter cover crops on nutrient cycling, soil quality and yield for production systems in the Mid-South. Degree of Master of Science, Faculty of the Louisiana State University and Agricultural and Mechanical College, B.S., EARTH University. 81 pp. 
Sainju, U.M., and Singh B.P. 1997. Winter cover crops for sustainable agricultural systems: Influence on soil properties, water quality, and crop yields. HortScience 32: 21-28.

Schonbeck M. and Morse R. 2006. Cover Crops for all seasons, expanding the cover crop tool box for organic vegetable producers. Virginia Association for Biological Farming Information Sheet. Number 3-06. (http://www.vabf.org/pubs.php).

Shakibafar, Z., Zaefarian, F., Rezvani, M. and Salehian H. 2016. Effect of cover crops on maize-velvet leaf competition: leaf area density and light interception. Acta Agriculturae Slovenica, 107(2): 409-418.

Smith R., Bettiga L., Cahn M., Baumgartner K., Jackson L.E. and Bensen T. 2008. Vineyard floor management affects soil, plant nutrition, and grape yield and quality. California Agriculture, 62 (4): 184-190. (http://CaliforniaAgriculture.ucop.edu).

Snapp, S.S., Swinton, S.M., Labarta, R., Mutch, D., Black, J.R., Leep, R., Nyiraneza, J. and O'Neil K. 2005. Evaluating cover crops for benefits, costs and performance within cropping system niches. Agronomy Journal, 97(1): 322-332.

Thomas F. and M. Archambeaud. 2012. Cover crops: some species observed, tested and mixed, from "TCS magazine", France, 7 pp. (http://www.agriculture-deconservation.com).

Weil, R., C. White and Lawley Y. 2009. Forage radish: new multi-purpose cover crop for the Mid-Atlantic. http://extension.umd.edu/publications/pdfs/fs824.// 